\title{
Variability patterns of microphytoplankton communities along the French coasts
}

\author{
I. Gailhard ${ }^{1, *}$, Ph. Gros ${ }^{1}$, J. P. Durbec ${ }^{2}$, B. Beliaeff ${ }^{3}$, C. Belin ${ }^{3}$, E. Nézan ${ }^{4}$, P. Lassus ${ }^{3}$ \\ ${ }^{1}$ IFREMER, BP 70, 29280 Plouzané, France \\ ${ }^{2}$ COM, Faculté des Sciences de Luminy, Case 901, 13288 Marseille Cedex 09, France \\ ${ }^{3}$ IFREMER, BP 21105, 44311 Nantes Cedex 3, France \\ ${ }^{4}$ IFREMER, 29187 Concarneau Cedex, France
}

\begin{abstract}
Microalgal populations along French coasts (English Channel, Bay of Biscay and Mediterranean Sea) have been sampled twice a month since 1987 within the context of the French Phytoplankton and Phycotoxin Monitoring Network (REPHY). This study used these data to characterize the large-scale geographical structures of microphytoplankton communities and to determine whether 'homogeneous' geographical areas exist in which microalgal populations display similar temporal variability schemes. Once the temporal variability component shared by all sampled coastal sites was identified, the 'residual' site-specific component was analyzed. Multivariate ordination methods were used to determine seasonal and inter-annual variability. The expected temporal pattern common to all sites was identified and the seasonal cycle of the most frequently observed phytoplankton communities along French coasts was described. The between-site analysis, using multitable comparison methods (RV-coefficient and multidimensional scaling), allowed the identification of 3 large areas (western English Channel, Bay of Biscay and Mediterranean Sea) according to the temporal variability patterns of microphytoplankton populations. The results, despite the coastal locations of REPHY sampling sites, indicate that the hydrodynamic characteristics of the different areas play a major role in the geographical structure of microalgal populations in French coastal waters.
\end{abstract}

KEY WORDS: Microphytoplankton · French coast · Geographical structure · Temporal variability · $\mathrm{RV}$-coefficient $\cdot$ Multidimensional scaling

\section{INTRODUCTION}

The dynamics of coastal marine microphytoplankton communities is characterized by successions of species assemblages displaying typical schemes of spatiotemporal variability (Smayda 1980). The succession of phytoplankton assemblages is mainly governed by local environmental conditions and by the response of phytoplankton populations to their variations (Goodman et al. 1984). The diversity and the dynamics of phytoplankton populations result from the complex interaction of hydrodynamical, physicochemical and biological factors.

*E-mail: igailhar@ifremer.fr
Numerous studies of phytoplankton spatio-temporal variability have concerned holistic variables such as total biomass or primary production (e.g. Radach \& Moll 1993). Such studies deal with the role of primary producers in the global functioning of the pelagic ecosystem, but have little relevance to other problematics. For instance, knowledge of the taxonomic composition of phytoplankton communities and of their spatio-temporal patterns is necessary to an understanding of the predominance of a precisely identified population. The dynamics of phytoplankton populations has been the subject of many recent studies concerning the development of harmful or toxic species (e.g. Rhodes et al. 1993). Indeed, the negative effects associated with the proliferation of some phytoplank- 


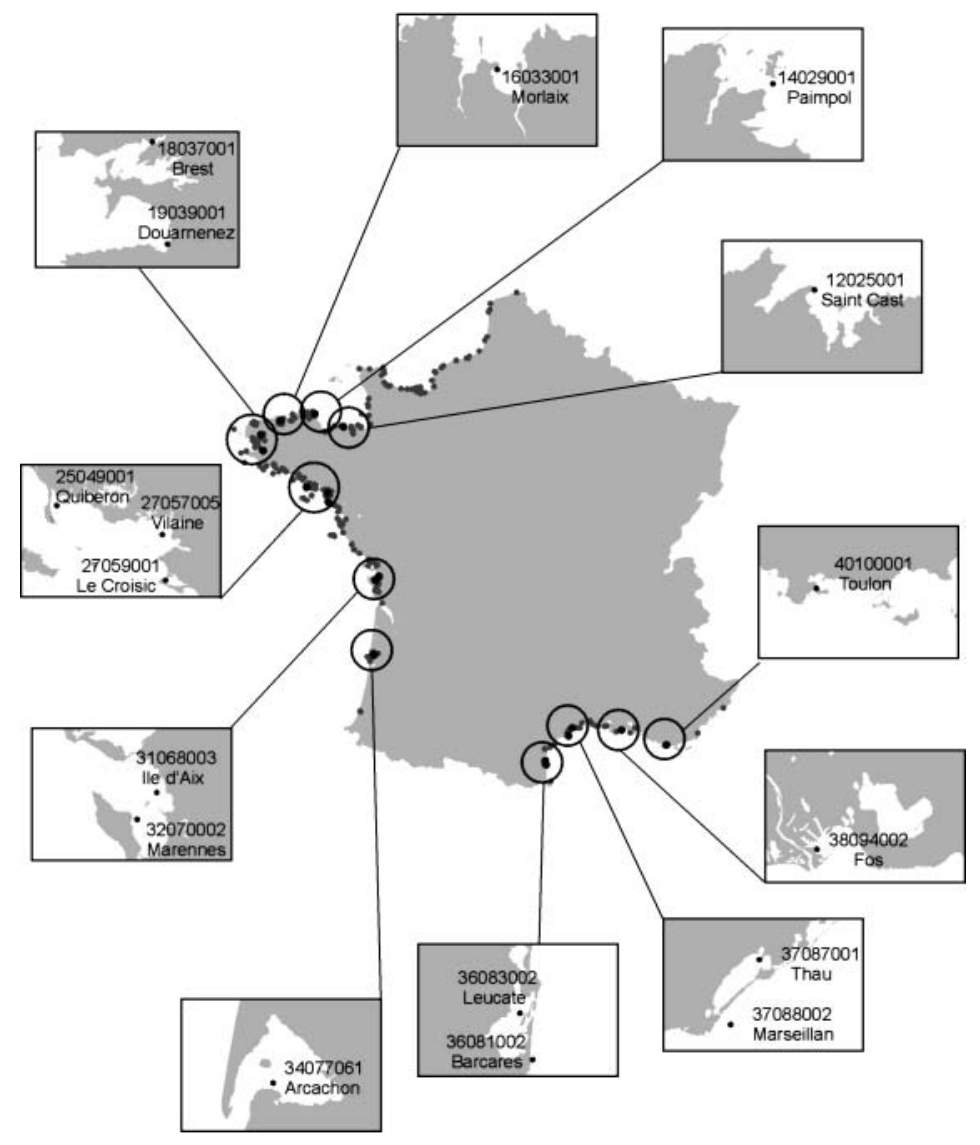

Fig. 1. Geographical location of REPHY sampling sites. Among these sites, those selected for processing correspond to black symbols: 17 sites for the temporal window, 1992 to 2000

ton species (economic losses to aquaculture, fisheries and tourism as well as an impact on human health) are such that the identification of environmental factors favoring their development is now of increasing interest (Zingone \& Enevoldsen 2000). However, the mechanisms of bloom species selection within phytoplankton communities are still unresolved (Smayda \& Reynolds 2001). In fact, it is essential to characterize the large-scale geographical and temporal patterns that determine the dynamics of phytoplankton communities over a wide area rather than those of an isolated population.

Until recently, little attention has been paid to the large-scale geographical and temporal patterns of phytoplankton communities, particularly because of the scarcity of long-term series on a large geographical scale. Successions of phytoplankton species have often been analyzed in localized areas (e.g. Hallegraeff \& Reid 1986), and phytoplankton species composition has been characterized and the 'dominant' species identified for different sampling sites (e.g. Belin et al.
1995). However, these studies do not take the combined effects of temporal and geographical variability into account.

The purpose of this study was to exploit the information contained in data collected within the context of the French Phytoplankton and Phycotoxin Monitoring Network (REPHY) as a significant basis for the description of the geographical distribution and temporal patterns of microphytoplankton communities. The objective was to identify the global temporal variability patterns of phytoplankton populations observed along French coasts and to determine biogeographical areas based on the temporal variability of phytoplankton populations. The methodological approach used for the analysis was based on descriptive multivariate techniques allowing multidimensional data to be summarized in a geometric space.

\section{MATERIALS AND METHODS}

REPHY sampling and pre-processing of data. The REPHY monitoring network was set up by IFREMER in 1984 to achieve 3 closely related objectives: (1) obtain knowledge about the temporal development of phytoplankton populations along French coasts, (2) record all types of unusual phytoplankton-related events in the coastal environment, whether toxic, harmful or harmless, and (3) detect any occurrence of phycotoxin-producing species and toxic events within a public health context (Belin \& Raffin 1998). Twenty-nine sites are sampled bimonthly along 3 French coastal areas (English Channel, Atlantic Ocean and Mediterranean Sea). Phytoplankton identification and counts are performed in 12 IFREMER coastal laboratories. The network provides 15-year time series, which constituted the basic material for this study. They were recorded in the IFREMER 'Quadrige' database according to a list of 275 taxa ranging from species identification level up to the Protista group.

The expertise of REPHY observers has gradually improved since 1984, especially through internal training sessions, expert assistance and the use of various teaching materials such as taxonomic data sheets. However, this progress has sometimes led to discontinuities in time series, e.g. 1 phytoplankton species was classified into different taxonomic levels between 1987 and 2000. Thus, the regrouping of taxonomic units was considered necessary not only because of the difficulties in taxonomic identification and confusions between species or genera, but also to obtain homoge- 
neous data sets (i.e. comparable for sampling sites and in time). A panel of experts (see 'Acknowledgements') were questioned about the relevance (ecological consistency) of regroupings.

A corrected data set for the period 1992 to 2000 with 78 taxonomic units was obtained. These units corresponded to a species, a regrouping of species, a genus, or a regrouping of genera. Due to problems in data quality, several taxa could not be retained for the analysis; consequently, some phytoplankton groups, such as Chlorophyceae, Chrysophyceae, Cryptophyceae, Cyanophyceae, Dictyochophyceae, Prasinophyceae, Prymnesiophyceae and Raphydophyceae, were not included in the study.

Monthly gap-free time series were used. As weather conditions did not always allow bimonthly sampling, a monthly abundance average was computed when 2 measurements were obtained in a month. These conditions allowed for inclusion of 17 of the 29 REPHY sampling sites (see locations in Fig. 1).

Temporal variability analysis. The notations used here are indicated in Table 1 . Let $A_{\text {stu }}$ be the abundance (cells $\mathrm{l}^{-1}$ ) of taxonomic unit $u$ measured at time $t$ (one of the months of the 1992 to 2000 period) at sampling site $s(s=1, \ldots, 17)$. Among the 78 taxonomic units retained after data preprocessing, 44 were selected on the basis of their occurrence percentages, being at least $0.20 \%$ relative to the total occurrences of all species. The list of the 44 taxonomic units selected for the analysis is indicated in Table 2.

Abundances were log-transformed: $X_{\text {stu }}=\log _{10}$ $\left(A_{\text {stu }}+1\right)$. In temperate coastal waters, phytoplankton communities are subject to a marked seasonal trend (Longhurst 1995, 1997). In order to identify the seasonal pattern (within-year variability) common to all sites, the mean $m_{\text {.tu }}$ and the variance $v_{a r}$.tu of $X_{\text {stu }}$ over all sampling sites were calculated. Thus, $2 T \times U$ (dates by taxonomic units) matrices $\mathbf{M}$ and $\mathbf{V}$ were computed over sites. Principal component analysis (PCA) was then performed to summarize the information contained in the average matrix $\mathbf{M}$ in order to describe the temporal variability pattern of taxonomic units on a large geographical scale.

The structure of the between-year variability of microphytoplankton populations was then explored after removal of the seasonal pattern by subtracting the monthly averages for each taxon from $m_{\text {.tu }}$. The matrix thus obtained was then summarized by PCA.

Analysis of geographical variability. Geographical variability was assessed through a between-site dissimilarity analysis. First, data were standardized in order to allow for spatial comparison:

$$
Z(s)_{. t u}=\frac{X_{s t u}-m_{. t u}}{\sqrt{v r_{. t u}}}
$$

Here, it is implicitly assumed that temporal and geographical effects are additive, i.e. that there is no interaction between time and space. In fact, such interaction exists; however, the removal of the general temporal pattern component shared by all sampling sites will result in a residual spatial trend. The second step was to identify the specific patterns of local variability, as each site is now characterized by the time variations of corrected abundances. For site $s(s=1, \ldots$, $S$ ), let $\mathbf{Z}_{(s)}$ be the $U \times T$ matrix with taxonomic units in rows and dates in columns. Due to standardization, column means in $\mathbf{Z}_{(s)}$ are 0 . In order to examine the between-site differences, the site matrices $\mathbf{Z}_{(s)}$ need to be compared. Various methods have been proposed for statistical analysis of multitables (e.g. 3-mode PCA by Tucker 1964, Kroonemberg 1983; triadic analysis by Thioulouse \& Chessel 1987; STATIS by Lavit et al.

Table 1. Notations used for data description

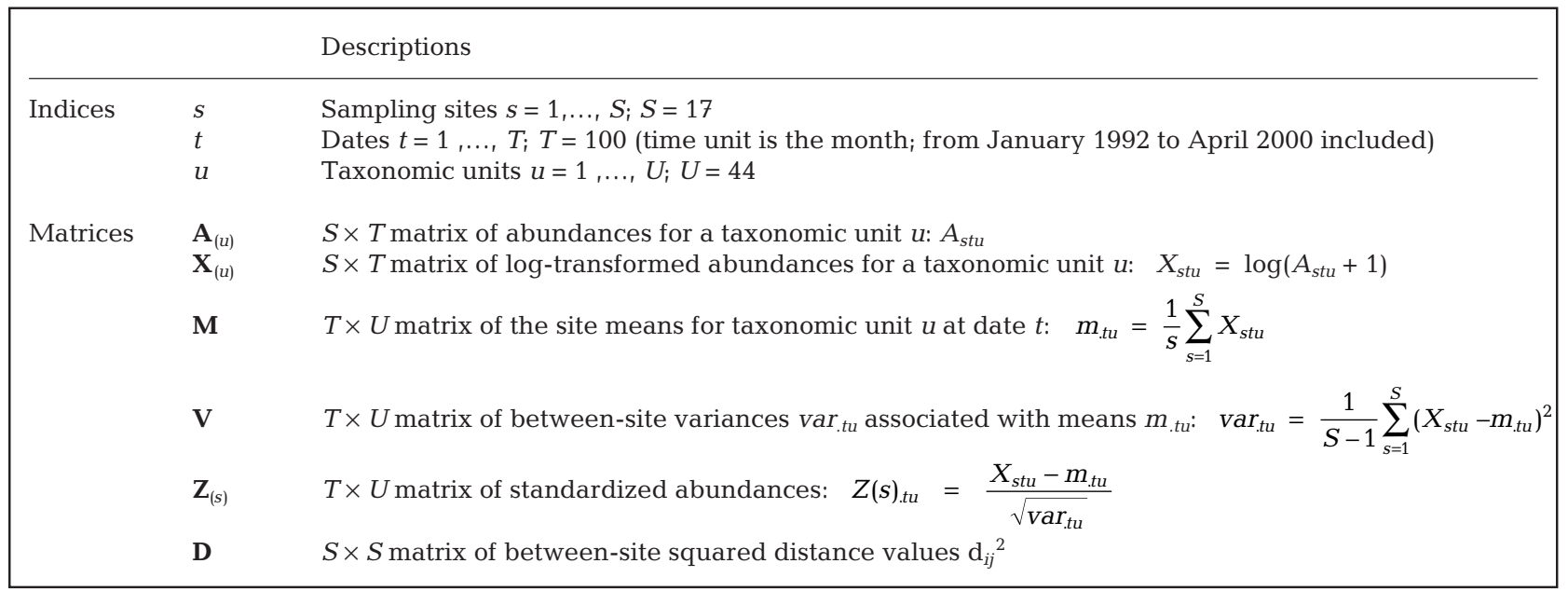


Table 2. List of 44 taxonomic units selected for data analysis

\begin{tabular}{|c|c|}
\hline \multicolumn{2}{|l|}{ Diatoms } \\
\hline $\mathrm{ACHN}$ & Achnanthes sp. \\
\hline ASTE & Asterionella sp. \\
\hline ASTEGLA & $\begin{array}{l}\text { Asterionella glacialis } \\
(=A \text {. japonica })\end{array}$ \\
\hline BACIPAX & $\begin{array}{l}\text { Bacillaria paxillifer } \\
(=B \cdot \text { paradoxa) }\end{array}$ \\
\hline $\mathrm{BACT}$ & Bacteriastrum sp. \\
\hline BELLITH & $\begin{array}{l}\text { Bellerochea sp. + } \\
\text { Lithodesmium sp. }\end{array}$ \\
\hline BIDODON & Biddulphia sp. + Odontella sp. \\
\hline CERAPEL & Cerataulina pelagica \\
\hline CHAE & Chaetoceros sp. \\
\hline DETLAUD & $\begin{array}{l}\text { Lauderia sp. + Schroederella sp. + } \\
\text { Detonula sp. }\end{array}$ \\
\hline DITYBRI & Ditylum brightwellii \\
\hline EUCPZOD & Eucampia zodiacus \\
\hline GRAM & Grammatophora sp. \\
\hline GUINFLA & Guinardia flaccida \\
\hline HEMI & Hemiaulus sp. \\
\hline LEPT & Leptocylindrus sp. \\
\hline LICM & Licmophora sp. \\
\hline NAVIC & $\begin{array}{l}\text { Amphora sp. + Diploneis sp. + } \\
\text { Navicula sp. }\end{array}$ \\
\hline NITZCYL & $\begin{array}{l}\text { Nitzschia longissima }+ \\
\text { Cylindrotheca closterium }\end{array}$ \\
\hline PORTHAL & $\begin{array}{l}\text { Porosira sp. + Thalassiosira sp. + } \\
\text { Coscinosira sp. }\end{array}$ \\
\hline PRORHIZ & Proboscia sp. + Rhizosolenia sp. \\
\hline PSNZ & Pseudo-nitzschia sp. \\
\hline RHABSTRI & Rhabdonema sp. + Striatella sp. \\
\hline SKELCOS & Skeletonema costatum \\
\hline THAA & Thalassionema sp. + Thalassiothrix sp. \\
\hline \multicolumn{2}{|c|}{ Dinoflagellates } \\
\hline ALEX & Alexandrium sp. \\
\hline ALEXMIN & Alexandrium minutum \\
\hline CERI & Ceratium sp. \\
\hline DINOAC & $\begin{array}{l}\text { Dinophysis acuminata }+ \\
\text { Dinophysis sacculus complex }\end{array}$ \\
\hline DINODI & Dinophysis caudata \\
\hline DINOROT & Dinophysis rotundata \\
\hline EBRARTRI & Ebria tripartita \\
\hline GONY & Gonyaulax sp. \\
\hline GONYSPI & Gonyaulax spinifera \\
\hline GYMN-82 & Gymnodinium chlorophorum \\
\hline GYMNNAG & $\begin{array}{l}\text { Gymnodinium nagasakiense } \\
\text { (= G. mikimotoi = Karenia mikimotoi) }\end{array}$ \\
\hline GYMNO & $\begin{array}{l}\text { Warnowia sp. + Nematodinium sp. + } \\
\text { Amphidinium sp. + Cochlodinium sp. }+ \\
\text { Gyrodinium sp. }+ \text { Katodinium sp. }+ \\
\text { Gymnodinium sp. }\end{array}$ \\
\hline NOCTSCI & Noctiluca scintillans \\
\hline PERID & $\begin{array}{l}\text { Diplopsalis sp. + Diplopelta sp. + } \\
\text { Diplopsalopsis sp. + Zygabikodinium } \\
\text { sp. + Oblea sp. }\end{array}$ \\
\hline PLESGYR & Pleurosigma sp. + Gyrosigma sp. \\
\hline POLYSCH & Polykrykos schwartzii \\
\hline PROR & Prorocentrum sp. (= Exuviaella sp.) \\
\hline PRORLIME & $\begin{array}{l}\text { Prorocentrum lima }+P . \text { marinum }+ \\
P . \text { mexicanum }\end{array}$ \\
\hline CLEUGLE & Euglenophyceae \\
\hline
\end{tabular}

1994; multifactorial analysis by Escofier \& Pagès 1994), but the results given by these methods are difficult to interpret when the number of tables is too large. Partly for this reason, multitable factorial analysis is not frequently used in oceanography, although this approach was used in earlier studies, e.g. on demersal assemblages (Gaertner et al. 1998), plankton communities (Beaugrand et al. 2000) and zooplankton communities (Licandro \& Ibanez 2000). In this study, PCA was used first to summarize each matrix site $\mathbf{Z}_{(s)}$, followed by a multitable method based on the RV-coefficient and metric multidimensional scaling (MDS) to allow comparison of these various summaries. PCA is a relevant tool for summarizing multidimensional data and has been used especially in oceanography (Manté et al. 1995, Gray et al. 1990, Ibanez \& Dauvin 1998). When Euclidean distance is used, results are not disturbed by rare species, contrary to other methods, such as multiple correspondence analysis based on chi-square metrics (Atchinson 1986, Manté et al. 1995).

Classically, the rows of the $\mathbf{Z}_{(s)}$ matrix (taxonomic units) are represented by points in Euclidean space $\mathrm{IR}^{\mathrm{T}}$. Let $\mathrm{C}\left(\mathbf{Z}_{(s)}\right)$ be the configuration of points associated with $\mathbf{Z}_{(s)}$. In order to compare temporal variations of the corrected abundances over sites, the shapes and relative positions of pairwise $\mathrm{C}\left(\mathbf{Z}_{(s)}\right)$ in $\mathrm{IR}^{\mathrm{T}}$ were analyzed. Two sites with similar configurations were considered to present the same temporal variations for all taxonomic units. Robert \& Escoufier (1976) showed that the distance between 2 configurations $\mathrm{C}\left(\mathbf{Z}_{(s)}\right)$ (or 2 sampling sites) can be estimated as follows:

$$
\mathrm{d}_{i j}{ }^{2}=\operatorname{dist}^{2}\left\{\mathrm{C}\left(\mathbf{Z}_{i}\right), \mathrm{C}\left(\mathbf{Z}_{j}\right)\right\}=2\left[1-\operatorname{RV}\left(\mathbf{Z}_{i}, \mathbf{Z}_{j}\right)\right]
$$

with

$$
\operatorname{RV}\left(\mathbf{Z}_{i}, \mathbf{Z}_{j}\right)=\frac{\operatorname{trace}\left(\mathbf{S}_{i j} \mathbf{S}_{j i}\right)}{\sqrt{\operatorname{trace}\left(\mathbf{S}_{i i}^{2}\right) \times \operatorname{trace}\left(\mathbf{S}_{j j}^{2}\right)}}
$$

(Escoufier 1973) and $\mathbf{S}_{i j}, \mathbf{S}_{i i}, \mathbf{S}_{j j}$ are the empirical matrices of variance-covariance calculated from $\mathbf{Z}_{i}$ and $\mathbf{Z}_{j}$ :

$$
\mathbf{S}_{i j}=\frac{1}{U} \mathbf{Z}_{i}^{\prime} \mathbf{Z}_{j} ; \quad \mathbf{S}_{i i}=\frac{1}{U} \mathbf{Z}_{i}^{\prime} \mathbf{Z}_{i} ; \quad \mathbf{S}_{j j}=\frac{1}{U} \mathbf{Z}_{j}^{\prime} \mathbf{Z}_{j}
$$

Between-site similarities are represented graphically by MDS. Let $\mathbf{D}$ be the Euclidean matrix of between-site squared distances. By using the $S(S-1) / 2$ between-site distances, the MDS method allows a configuration of $S$ points in $\operatorname{IR}^{k}(k \leq S)$ to be estimated, such that the usual Euclidean distance between these points is equal to the between-site distances in the $\mathbf{D}$ matrix (Krzanowski 1982). The proximities between sites can be displayed on 1 or several bidimensional plots according to the dimension $k$, which is necessary to obtain distances between vectors close to those in $\mathbf{D}$.

The RV-coefficient-MDS combination can be considered as a simplified STATIS method (Escoufier 1973, Lavit et al. 1994). In our case, the identification of 
the taxonomic units responsible for between-site differences was indirectly examined by computing the ratio of the between-site variance to the within-site variance of each $X_{\text {stu }}$. Taxa with a high ratio value displayed different temporal variability patterns from one site to another. lated. Fig. 4 shows the inter-annual variability of taxonomic units (the genera group Navicula sp. + Diploneis sp. + Amphora sp., the genus Pseudonitzschia sp., the species Karenia mikimitoi, and the genera regrouping Gymnodinium sp. + Amphidinium sp. + Cochlodinium sp. + Gyrodinium sp. + Katodinium sp. + Warnowia sp.

\section{RESULTS}

\section{Seasonal patterns}

Fig. 2a shows representations of individuals (dates) in the first factorial plane of matrix M PCA, with $40 \%$ of variance explained. Date coordinates show obvious intra-annual variability, and variables' representation (taxonomic units, figure not shown) in dual space associate the species with similar intra-annual variability, allowing identification of a seasonal cycle of taxonomic units. Axis 1 opposes taxonomic units with summer concentration maxima against taxonomic units with winter concentration maxima, and Axis 2 opposes taxonomic units with spring concentration maxima against taxonomic units with fall concentration maxima. Fig. 3 provides an example of the temporal variability of taxonomic units strongly correlated with the first and second axes. The 'summer' genus Leptocylindrus sp. (LEPT code) is opposed to the 'winter' genera group Porosira sp. + Thalassiosira sp. + Coscinosira sp. (PORTHAL code) on Axis 1 (Fig. 3a), and the 'fall' genera group Thalassionema sp. + Thalassiothrix sp. (THAA code) is opposed to the 'spring' genera group Dinophysis acuminata $+D$. sacculus (DINOAC code) on Axis 2 (Fig. 3b).

\section{Between-year changes}

PCA performed on the matrix of seasonally adjusted $m_{. t u}$ exhibited a marked between-year structure, visible in the representation of individuals on both first main axes (Fig. 2b). Almost $25 \%$ of the variance is explained by the first 2 principal components. The dual representation (Fig. not shown) allowed the most contributing variables in the explanation of temporal variability structure to be iso- a
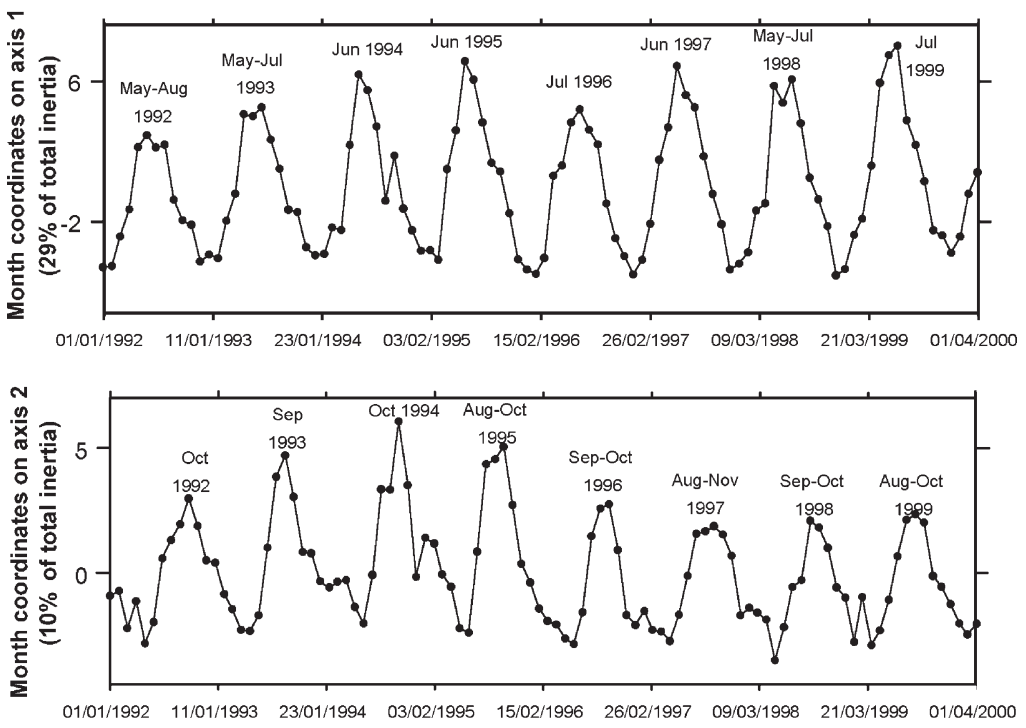

b
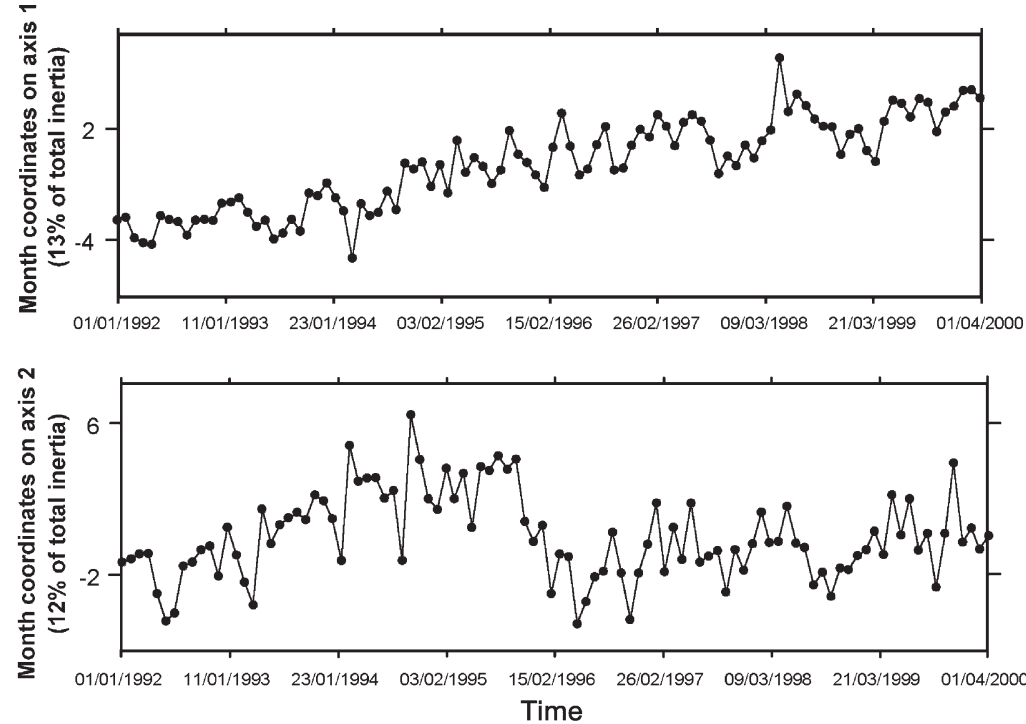

Fig. 2. Temporal variability analysis. (a) Seasonal pattern identification: PCA of the $100 \times 44$ (dates by taxonomic units) matrix of monthly means of logtransformed abundances over sites. Plot of the month coordinates in the first factorial plane (39\% of variance). Winter and summer months are opposed on Axis 1, and spring and fall months on Axis 2. (b) Between-year variability analysis: PCA of the $100 \times 44$ (dates by taxonomic units) matrix of monthly means over sites, corrected from the monthly component. Plot of the month coordinates in the first factorial plane ( $25 \%$ of variance). Axis 1 shows a break between 1994 and 1995 
+ Nematodinium sp.) strongly correlated with both first principal components.

\section{Between-site differences}

Between-site squared distance values were from 0 to 2 per construction, with most of the estimated distances ranging from 1 to 1.5 . The distribution of distances (few short distances) and analysis of the stability of results (calculation of distances between tables built by inverting rows of the 17 initial tables) showed that the observed between-site structure was not due to a random effect. The first 3 eigenvalues of the matrix used for multidimensional scaling allowed $30 \%$ of the original distances to be reconstructed.

Multidimensional scaling results (Fig. 5) point to a geographical effect, i.e. (1) Saint Cast, Paimpol and Morlaix sites in the Western English Channel are grouped with positive coordinates on Axis 1 and negative coordinates on Axis 2; (2) Bay of Biscay sites (Douarnenez, Quiberon, Vilaine, Le Croisic, Noirmoutier, Marennes and Ile d'Aix) have similar positions on Axis 1 (negative coordinates) and Axis 3 (positive coordinates); and (3) Mediterranean sites (Bar-cares, Leucate, Marseillan, Thau, Fos and Toulon) are grouped on Axes 1 and 3 (negative coordinates).

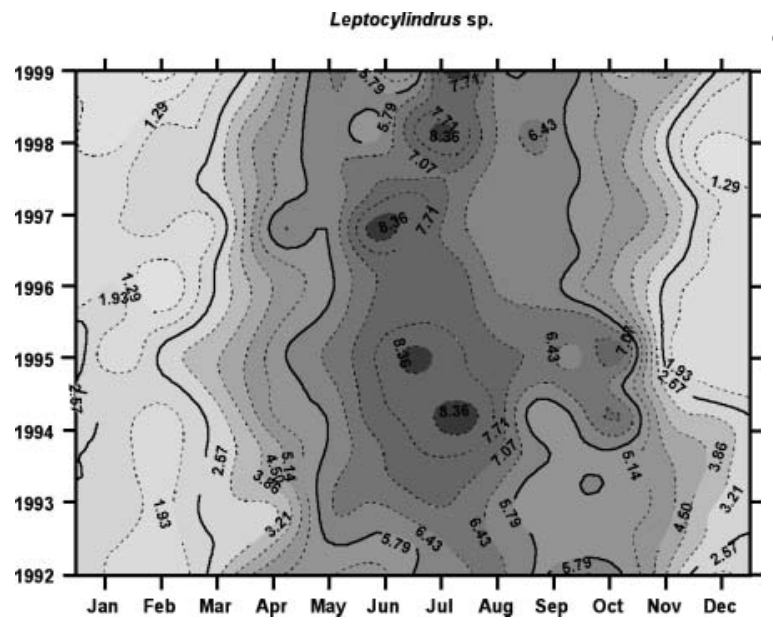

a
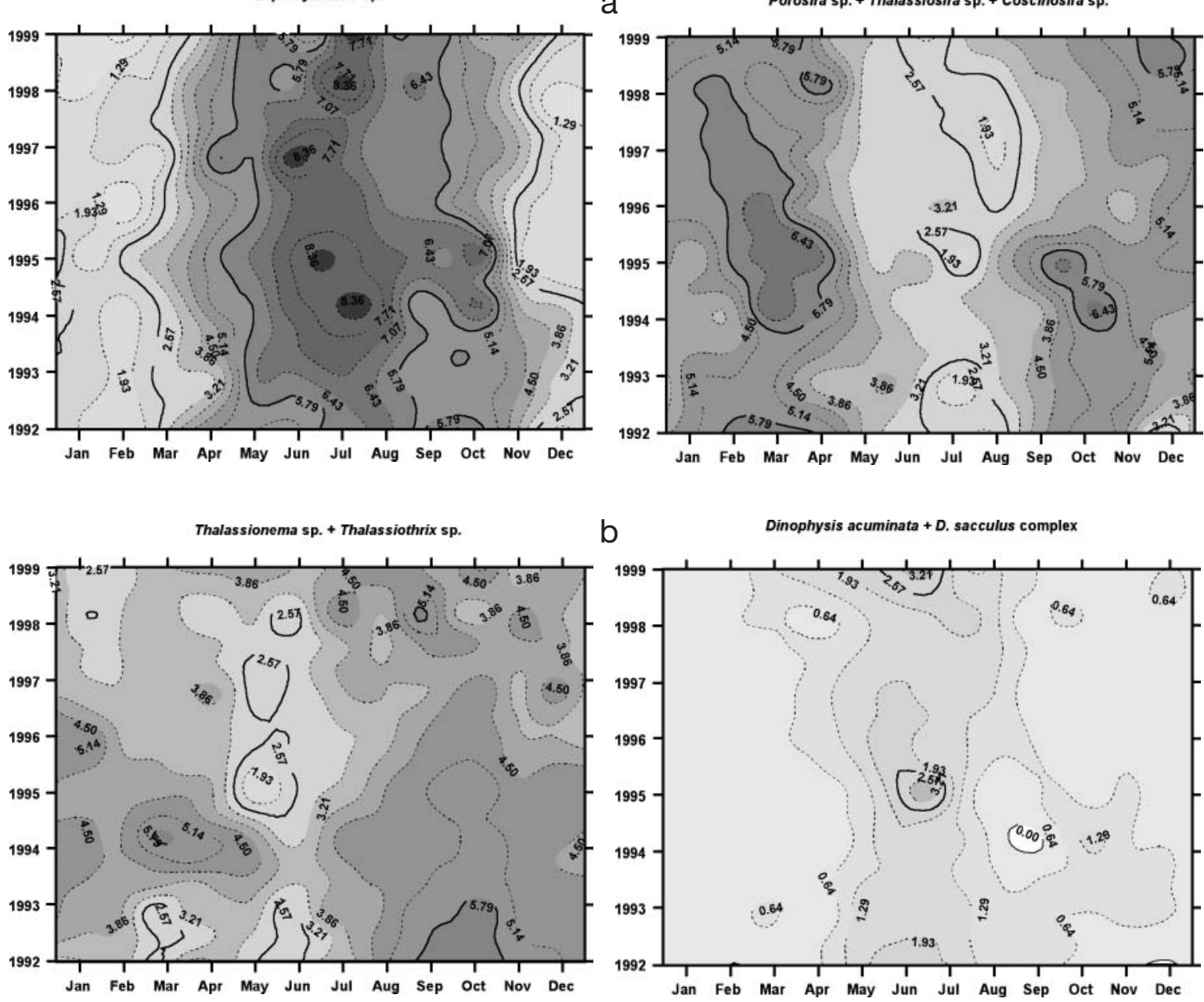

b

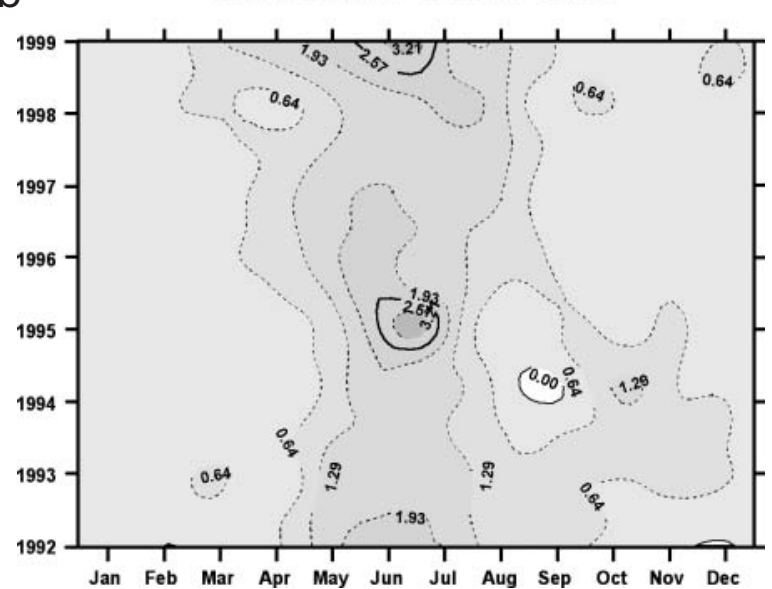

Fig. 3. Description of intra-annual variability. (a) Within- and between-year concentrations means (log cell $1^{-1}$ ) overall sites for the period 1992 to 2000 of LEPT and PORTHAL. The genus Leptocylindrus sp. (LEPT code) shows maximal concentrations during summer months (June to August), when the concentrations of the genera Porosira sp. + Thalassiosira sp. + Coscinosira sp. (PORTHAL code) are minimal; these genera reach maximum concentrations during February to March. (b) Within- and between-year concentrations means ( $\log$ cell $\mathrm{l}^{-1}$ ) overall sites for the period 1992-2000 of THAA and DINOAC. The genera regrouping Thalassionema sp. + Thalassiothrix sp. (THAA code) present maximal concentrations during September to October, and D. acuminata + D. sacculus complex (DINOAC code) during May to June 
The taxonomic units with the 10 highest ratios of between-site variance to within-site variance, with their ecological characteristics and their geographical distribution, are indicated in Table 3. Geographical distribution of these taxa was identified by examining their temporal variability at each sampling site (Figs. not shown). Among the 10 taxonomic units, most (7) are diatoms, characterizing, in particular, the western English Channel (Asterionnella glacialis and Rhizosolenia delicatula) and the Mediterranean lagoons (Grammatophora sp., Licmophora sp., and Navicula sp. + Diploneis sp. + Amphora sp.). The dinoflagellates class is represented by a genera regrouping abundant in the Bay of Biscay (Gymnodinium sp. + Amphidinium sp. + Cochlodinium sp. + Gyrodinium sp. + Katodinium sp. + Warnowia sp. +
Nematodinium sp.) and by a species regrouping of the genus Prorocentrum characteristic of open sea Mediterranean sites. Note the presence of the Euglenophyceae class, mainly composed of freshwater species, and frequent in the Bay of Biscay. From the ecological point of view, 2 groups can be distinguished: pelagic and benthic or tychopelagic (fixed on a substrate) species.

\section{DISCUSSION}

\section{Seasonal patterns}

The examination of seasonality (Figs. 2a \& 3) shows that the temporal variability of phytoplankton popula-

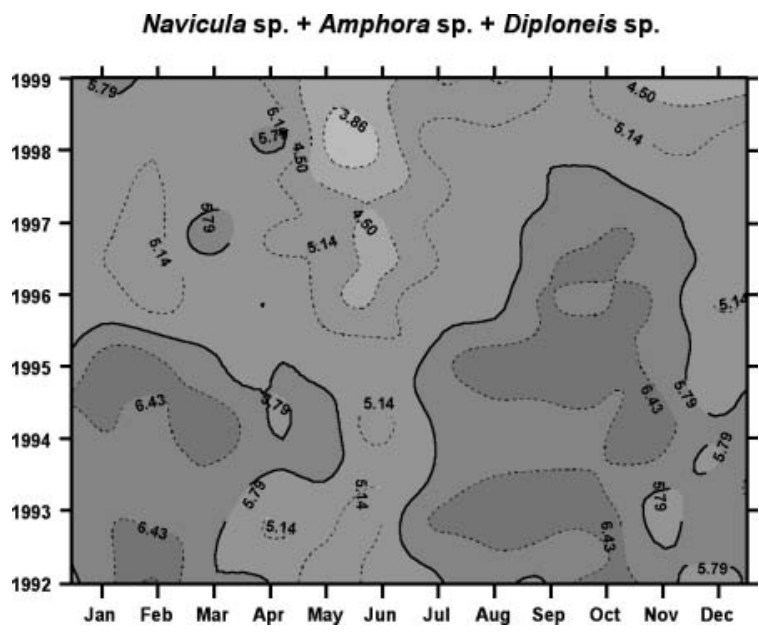

a

Pseudonitzschia sp.

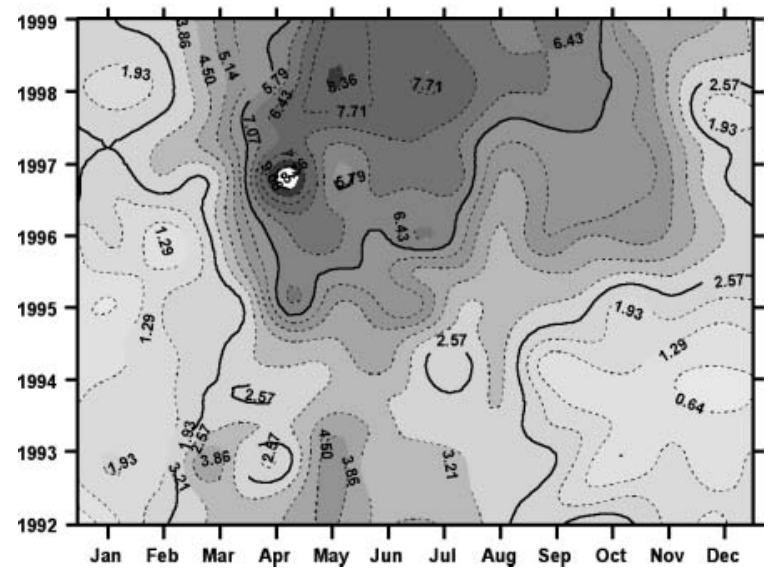

b

Gymnodinium sp. (including catenatum, splendens) + Amphidinium sp. + Cochlodinium sp. +

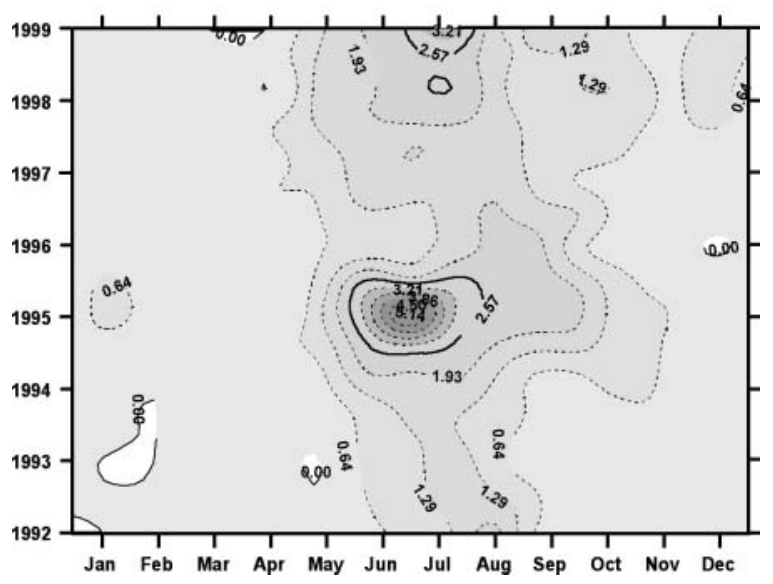

Gyrodinium sp. + Katodinium sp. + Warnowia sp. + Nematodinium sp.

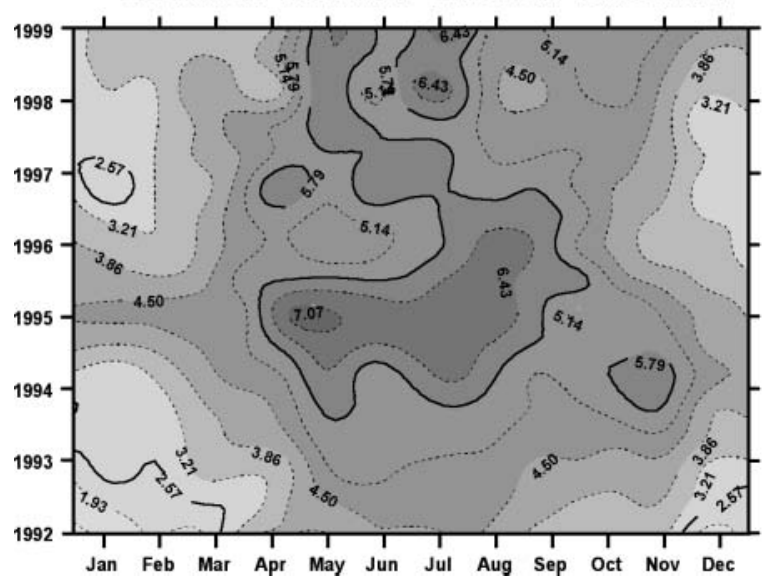

Fig. 4. Description of inter-annual variability. (a) Within- and between-year concentrations means $\left(\log\right.$ cell $\left.1^{-1}\right)$ overall sites for the period 1992 to 2000 of NAVIC and PSNZ. The high concentrations of the genera regrouping Navicula sp. + Diploneis sp. + Amphora (code NAVIC) observed between January and April decrease from 1995, whereas for Pseudo-nitzschia sp. genus (code PSNZ) an increase is observed for high spring-summer concentrations from 1995. (b) Within- and between-year concentrations means $\left(\log\right.$ cell $^{-1}$ ) overall sites for the period 1992 to 2000 of GYMNNAG and GYMNO. An increase is observed in high summer concentrations from 1995, with an exceptional increase in 1995 spring-summer concentrations 


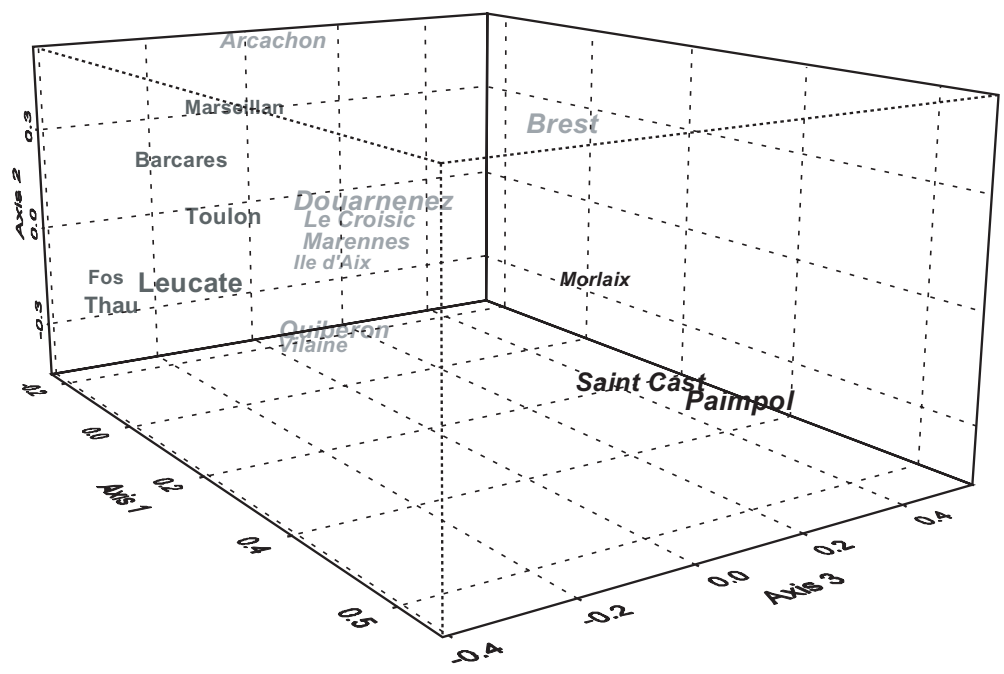

Fig. 5. Multidimensional scaling of between-site squared distance matrix. Different text symbols are used to distinguish the 3 French coastal areas. The size of the characters is proportional to the coordinate on Axis 1. Note the eccentric positions of the Arcachon and Brest sites in temperate coastal areas (e.g. Longhurst 1995, 1997). Fig. 6, which shows the seasonal distribution of the 44 taxonomic units selected, confirms the opposition of wintersummer species (Axis 1) and spring-fall species (Axis 2), as displayed in Fig. 2a, and allows the succession of communities to be described. The seasonal progression from diatom- (Fig. 6b) to dinoflagellate-dominated communities (Fig. 6a) illustrates the basic characteristics of phytoplankton succession in temperate coastal waters (Smayda 1980). These typical, well-known successions are usually associated with nutrient enrichment in a well-mixed water column triggering the spring, fall and winter blooms and with the input of nutrients into a stratified water column for the supply of summer blooms (Hallegraeff \& Reid 1986). The summer dinoflagellate community (codes ALEX to PRORLIME, Fig. 6a) follows the spring diatom bloom (codes THAA to BACT, Fig. 6b). Most dinoflagellate species are characterized by abundance maxima between May and August, whereas diatom species are present in high numbers yearround, in particular with a distinct group of winter-fall species (code THAA to DETLAUD, Fig. 6b). These seasonal patterns have also been described in other studies. For example, diatom species in temperate coastal tions in French metropolitan coastal waters is subject to a marked seasonal cycle, with the exception of some species or genera, such as the Navicula sp. + Amphora sp. + Diploneis sp. group (cf. Fig. 4a) which are present all year-round. This has been confirmed by other studies focussing on changes of phytoplankton populations

Table 3. Inter-intra-sampling site variances: 10 first contributory taxonomic units. Geographical distribution and ecological characteristics show that the western English Channel is characterized by 2 pelagic diatoms, and the Bay of Biscay by dinoflagellates and Euglenophyceaea. Mediterranean sites are divided into lagoons (characterized by benthic diatoms) and open sea sites (characterized by warm water taxonomic units)

\begin{tabular}{|c|c|c|c|}
\hline Code & Taxonomic units & Geographical distribution & Ecological characteristics* \\
\hline ASTEGLA & Asterionella glacialis (pennate diatom) & Western English Channel & $\begin{array}{l}\text { Abundant in cold marine and coastal } \\
\text { waters to temperate-pelagic }\end{array}$ \\
\hline GYMNO & $\begin{array}{l}\text { Gymnodinium sp. }+ \text { Amphidinium sp. + } \\
\text { Cochlodinium sp. }+ \text { Gyrodinium sp. }+ \\
\text { Katodinium sp. }+ \text { Warnowia sp. }+ \\
\text { Nematodinium sp. (dinoflagellate) }\end{array}$ & Bay of Biscay & $\begin{array}{l}\text { Abundant in coastal waters-pelagic } \\
\text { (exception for some Katodinium species) }\end{array}$ \\
\hline GRAM & $\begin{array}{l}\text { Grammatophora sp. } \\
\text { (pennate diatom) }\end{array}$ & Mediterranean lagoons & $\begin{array}{l}\text { Abundant in warm marine waters to } \\
\text { temperate-benthic to tychopelagic }\end{array}$ \\
\hline CLEUGLE & Euglenophyceae & Bay of Biscay & Mainly freshwater species \\
\hline LICM & Licmophora sp. (pennate diatom) & Mediterranean lagoons & $\begin{array}{l}\text { Abundant in marine waters, cosmopolite } \\
\text { - benthic to tychopelagic }\end{array}$ \\
\hline RHIZDEL & $\begin{array}{l}\text { Rhizosolenia delicatula } \\
\text { (centric diatom) }\end{array}$ & Western English Channel & Abundant in marine waters - pelagic \\
\hline NAVIC & $\begin{array}{l}\text { Navicula sp. + Diploneis sp. }+ \\
\text { Amphora sp. (pennate diatom) }\end{array}$ & Mediterranean lagoons & $\begin{array}{l}\text { Abundant in coastal waters - benthic } \\
\text { to tychopelagic }\end{array}$ \\
\hline NITZCYL & $\begin{array}{l}\text { Nitzschia longissima }+ \\
\text { Cylindrotheca closterium } \\
\text { (pennate diatom) }\end{array}$ & Bay of Biscay & $\begin{array}{l}\text { Abundant in marine waters - benthic } \\
\text { to tychopelagic }\end{array}$ \\
\hline PRORHIZ & $\begin{array}{l}\text { Proboscia alata + Rhizosolenia sp. } \\
\text { (centric diatom) }\end{array}$ & Open Mediterranean Sea & Abundant in marine waters - pelagic \\
\hline PRORMIN & $\begin{array}{l}\text { Prorocentrum minimum }+P \text {. balticum }+ \\
\text { P. cordatum (dinoflagellate) }\end{array}$ & Open Mediterranean Sea & $\begin{array}{l}\text { Abundant in estuarine and coastal } \\
\text { waters - pelagic }\end{array}$ \\
\hline
\end{tabular}


waters, such as Skeletonema costatum (SKELCOS) or Thalassiosira nordenskioldii (species included in the Porosira sp. + Thalassiosira sp. group, PORTHAL code) have been identified as dominant winter-spring outbursting species (Levasseur et al. 1984, Marshall \& Lacouture 1986). Along French coasts, Rhizosolenia sp. (grouped with Proboscia sp., PRORHIZ code) has been described as a genus blooming in late winter and early spring, and Dinophysis sp. as a summer genus (late spring-early summer for DINOAC and DINOROT, and late summer for DINODI in our results) (Videau et al. 1998, Beliaeff et al. 2001).

\section{Between-year changes}

Analysis of inter-annual variability revealed a significant break between 1994 and 1995 (Fig. 2b), which was confirmed by the temporal variability of the taxonomic units involved (Fig. 4). Interpretation is difficult, as only $25 \%$ of the variance could be explained by the first factorial plane. Moreover, every species or genus concerned would require detailed specific interpretation in any given area, which was not performed in this study. However, identification of phytoplankton populations subject to unusual between-year temporal variability (e.g. exceptional development of a population in a given year) would be of particular interest with respect to harmful taxa and could be helpful in characterizing the environmental factors favorable to their development. For example, exceptional physical conditions were observed in the Bay of Biscay during 1994-1995. The plumes of 2 large river estuaries (Loire and Gironde) on the French Atlantic coast, which have an important physical influence on phytoplankton growth, overlapped during these years (Labry et al. 2001). These extraordinary conditions, caused by abnormal wind regime, and increase of the Gironde runoff, may have been the reason for the break, by affecting phytoplankton growth through the haline stratification (Levasseur et al. 1984). PCA results show that the extensive development of Karenia mikimotoi (GYMNNAG code) in 1995 at Bay of Biscay sites was a significant factor ac- counting for the structure of inter-annual variability (Fig. 4b). The bloom was not limited to its usual area of occurrence (western Brittany), but extended along the entire French Atlantic coast, causing exceptional losses of marine fauna (Gentien et al. 1998). The same
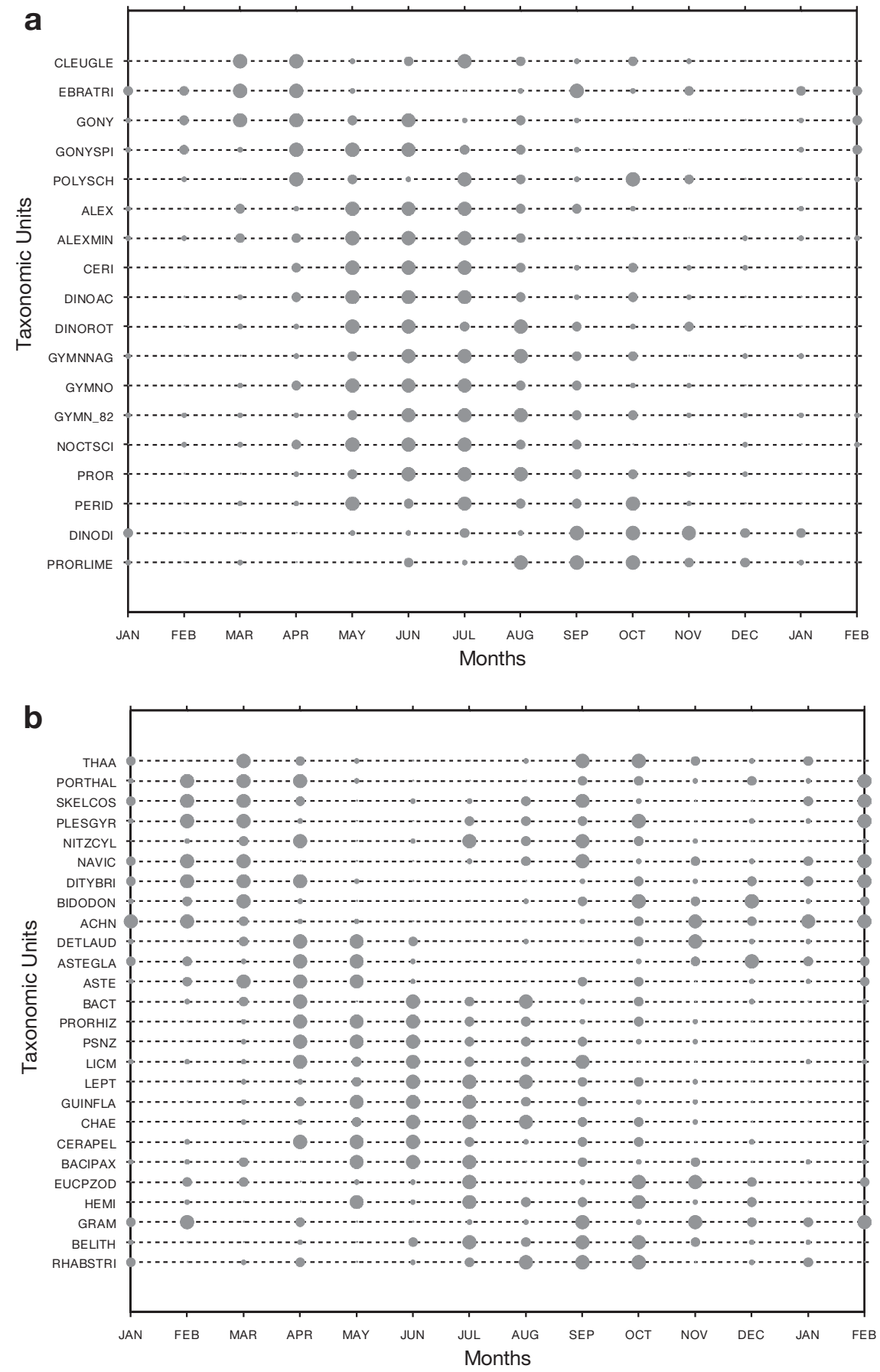

Fig. 6. Seasonal distribution of (a) dinoflagellate taxonomic units and the Euglenophyceae group (CLEUGLE) and (b) diatom taxonomic units recorded along French coasts for the period 1992 to 2000. Symbol size is proportional to log-transformed maximum monthly abundance 
1995 event also involved multi-species blooms of such genera as Warnowia sp., Nematodinium sp., Amphidinium sp., Cochlodinium sp., Gyrodinium sp., Katodinium sp. and Gymnodinium sp. (Fig. 4b).

\section{Between-site differences}

Removal of the seasonal trend facilitated the identification of 3 distinct geographical areas (western English Channel, Bay of Biscay, Mediterranean Sea; see Fig. 5). Changes in the dynamics of the species that contributed significantly to the geographical structure, as identified by the ratio of between-site to within-site variance (Table 3), seem to be associated with different physical properties of the water column. The state-ofthe-art knowledge about the ecology of these species corroborated the close association found in our study between the distribution of the different phytoplankton assemblages and the hydrographic characteristics of the area (e.g. tidal current and wind regimes). Indeed, there is a close association between species composition of phytoplankton communities and the stratification of the water column, especially on diatoms/ dinoflagellates predominance. Turbulence inhibits dinoflagellate growth by causing physical damages, physiological impairment and behavioral modification, whereas diatoms are considerably less sensitive to turbulence (Thomas \& Gibson 1990, Smayda 1997, Smayda \& Reynolds 2001). The French western English Channel coasts, where low freshwater inputs and physical forcing by high tidal amplitudes create a vertical mixing throughout the year (Garreau 1993), are characterized by two diatoms (Asterionnella glacialis and Rhizosolenia delicatula). The predominance of diatoms due to the vertical mixing of water column in this area has been described by other studies (e.g. Maddock et al. 1981, Videau et al. 1998). In contrast to the western English Channel coast, the French coasts of the Bay of Biscay are subjected to significant freshwater inputs (mainly from the Loire, Gironde and Adour rivers) accounting for the co-occurrence of typical marine species (e.g. Nitzschia longissima) and freshwater species (Euglenophyceae) (Dauvin 1997). In this area, tidal currents are lower, and the circulation is mainly wind-driven. In summer, the spreading of freshwater over the shelf induced by upwelling favourable winds from NW, and the occurrence of a thermocline (Lazure \& Jegou 1998), induce a stratification of the water column favorable to the development of dinoflagellates, such as Gymnodinium sp., Gyrodinium sp. and Katodinium sp. (Marshall \& Cohn 1983). Mediterranean sites are divided into 2 groups: open sea and lagoon sites. In open sea sites, hydrological characteristics are closely associated with very small tidal amplitudes, and also marked by waters discharged by the Rhône river (Beckers et al. 1997). The summer formation and deepening of a seasonal thermocline and transient wind-induced upwellings (Johns et al. 1992) allow the development of warm water dinoflagellates as Prorocentrum minimum (Videau \& Leveau 1990). Mediterranean lagoons are described as diatoms-dominated ecosystems (Jarry et al. 1990). Because of their shallow depths, these lagoons are all year long well-mixed; this water column mixing is responsible for the presence of benthic diatoms as Licmophora sp. and Grammatophora sp. (Vaulot \& Frisoni 1986).

\section{CONCLUSION}

Data collected in the context of the REPHY monitoring network constitute a significant basis for examining the large-scale temporal and geographical variability of phytoplankton communities. Mainly due to changes among the observers responsible for species identification, this study required meticulous pretreatment of data, especially with respect to a comprehensive regrouping of genera or species by a group of experts. Although extremely time-consuming, this validity checking phase was a crucial preliminary phase in our study: it gave us confidence in our results and, in terms of monitoring program management, provided final guidance for phytoplankton identification and corresponding coding in the database. Our qualified data set allowed to describe the temporal variability scheme, and particularly to illustrate the global seasonal trend for the most frequently observed species along French coasts. Moreover, geographical areas exhibiting similar phytoplankton population dynamics were identified. As REPHY sampling sites are located near the coast, the identification of homogeneous geographical areas was not a predictable result. Indeed, in the context of REPHY sampling, local characteristics, as anthropogenic impacts, are supposed to dominate. This illustrates the importance of hydrodynamic properties to the structure of coastal phytoplankton communities. Determination of the large geographical scale structure of microphytoplankton populations along French coasts should facilitate research concerning the 'discriminant' species characteristics of a geographical area and the effects of the environmental factors controlling the dynamics of these populations. As phytoplankton populations display similar temporal patterns within large geographical areas, a thorough study of the hydrodynamic characteristics of these areas could identify the physical parameters influencing the dynamics of these populations. 
Acknowledgements. The authors are grateful to the experts who contributed to the study: C. Billard (University of Caen, France), J. D. Dodge (University of London, England), V. Martin-Jézéquel (University of Brest, France), G. Paulmier (CREMA, L'Houmeau, France), Y. Rincé (University of Nantes, France) and D. Vaulot (Station Biologique, Roscoff, France). We also acknowledge the assistance of the 12 IFREMER coastal laboratories responsible for water sample collection and phytoplankton identification, and B. Raffin (IFREMER Nantes) for drawing the maps. This study was supported by the French National Program for the Coastal Environment (PNEC).

\section{LITERATURE CITED}

Atchinson J (1986) The statistical analysis of compositional data. Chapman \& Hall, London

Beaugrand G, Ibanez F, Reid PC (2000) Spatial, seasonal and long-term fluctuations of plankton in relation to hydroclimatic features in the English Channel, Celtic Sea and Bay of Biscay. Mar Ecol Prog Ser 200:93-102

Beckers JM, Brasseur P, Nihoul JCJ (1997) Circulation of the western Mediterranean: from global to regional scales. Deep-Sea Res II 44:531-549

Beliaeff B, Gros P, Belin C, Raffin B, Gailhard I, Durbec JP (2001) 'Phytoplankton events' in French coastal waters during 1987-1997: identification, and qualitative study of large-scale spatiotemporal structures. Oceanol Acta 24: 425-433

Belin C, Raffin B (1998) Les espèces phytoplanctoniques toxiques et nuisibles sur le littoral français, résultats du REPHY (réseau de surveillance du phytoplancton et des phycotoxines). Rapp Int IFREMER/RST.DEL/MP-AO 98-16

Belin C, Beliaeff B, Raffin B, Rabia M, Ibanez F (1995) Phytoplankton time-series data of the French Phytoplankton Monitoring Network: toxic and dominant species. In: Lassus P, Arzul G, Erard Le Denn E, Gentien P, Marcaillou Le Baut C (eds) Harmful marine algal blooms-Proliférations d'algues nuisibles. Paris-France Lavoisier, p 771-776

Dauvin JC (1997) Les biocénoses marines et littorales françaises des côtes Atlantiques, Manche et Mer du Nord: synthèses, menaces et perspectives. Laboratoire de Biologie des Invertébrés Marins et Malacologie-Service du Patrimoine naturel/IEGB/MNHN, Paris

Escofier B, Pagès J (1994) Multiple factor analysis (AFMULT package). Comput Stat Data Anal 18:121-140

Escoufier Y (1973) Le traitement des variables vectorielles. Biometrics 29:751-760

Gaertner JC, Chessel D, Bertrand J (1998) Stability of spatial structures of demersal assemblages: a multitable approach. Aquat Living Resour 11:75-85

Garreau P (1993) Hydrodynamics of the north Brittany coast: a synoptic study. Oceanol Acta 16:469-477

Gentien P, Lazure P, Raffin B (1998) Effect of meteorological conditions in spring on the extent of Gymnodinium cf. nagasakiense bloom. In: Reguera B, Blanco J, Fernandez ML, Wyatt $\mathrm{T}$ (eds) Harmful Algae. Xunta de Galicia and Intergovernmental Oceanographic Commission of UNESCO, Paris, p 200-203

Goodman D, Eppley RW, Reid FMH (1984) Summer phytoplankton assemblages and their environmental correlates in the Southern California Bight. J Mar Res 42: 1019-1049

Gray JS, Clarke KR, Warwick RM, Hobbs G (1990) Detection of initial effects of pollution on marine benthos: an ex- ample from the Ekofisk and Eldfisk oilfields, North Sea. Mar Ecol Prog Ser 66:285-299

Hallegraeff GM, Reid DD (1986) Phytoplankton species successions and their hydrological environment at a coastal station off Sydney. Aust J Mar Freshwat Res 37:361-377

Hendey NI (1964) An introductory account of the smaller algae of british coastal waters. Part V. Bacillariophyceae. Her Majesty's Stationery Office, London

Ibanez F, Dauvin JC (1998) Shape analysis of temporal ecological process: long-term changes in English Channel macrobenthic communities. Coenoses 13:115-129

Jarry V, Fiala M, Frisoni GF, Jacques G, Neveux J, Panouse M (1990) The spatial distribution of phytoplankton in a Mediterranean lagoon (Etang de Thau). Oceanol Acta 13: 503-512

Johns B, Marsaleix P, Estournel C, Véhil R (1992) On the wind-driven coastal upwelling in the Gulf of Lions. J Mar Syst 3:309-320

Kroonemberg PM (1983) Three-mode principal components analysis. DSWO Press, Leiden

Krzanowski WJ (1982) Between-group comparison of principal components - some sampling results. J Statist Comput Simul 15:141-154

Labry C, Herbland A, Delmas D, Laborde P, Lazure P, Froidefond JM, Jegou AM, Sautour B (2001) Initiation of winter phytoplankton blooms within the Gironde plume waters in the Bay of Biscay. Mar Ecol Prog Ser 212:117-130

Lavit C, Escoufier Y, Sabatier R, Traissac P (1994) The ACT (STATIS method). Comput Stat Data Anal 18:97-119

Lazure P, Jegou AM (1998) 3D modelling of seasonal evolution of Loire and Gironde plumes on Biscay Bay continental shelf. Oceanol Acta 21:165-177

Levasseur M, Therriault JC, Legendre L (1984) Hierarchical control of phytoplankton succession by physical factors. Mar Ecol Prog Ser 19:211-222

Licandro P, Ibanez F (2000) Changes of zooplankton communities in the Gulf of Tigullio (Ligurian Sea, western Mediterranean) from 1985 to 1995: influence of hydroclimatic factors. J Plankton Res 22:2225-2253

Longhurst A (1995) Seasonal cycles of pelagic production and consumption. Prog Oceanogr 36:77-167

Longhurst A (1997) Ecological geography of the sea. Academic Press, London

Maddock L, Boalch GT, Harbour DS (1981) Populations of phytoplankton in the western English Channel between 1964 and 1974. J Mar Biol Assoc UK 61:565-583

Manté C, Dauvin JC, Durbec JP (1995) Statistical method for selecting representative species in multivariate analysis of long-term changes of marine communities. Applications to a macrobenthic community from the Bay of Morlaix. Mar Ecol Prog Ser 120:243-250

Marshall HG, Cohn MS (1983) Distribution and composition of phytoplankton in northeastern coastal waters of the United States. Estuar Coast Shelf Sci 17:119-131

Marshall HG, Lacouture R (1986) Seasonal patterns of growth and composition of phytoplankton in the lower Chesapeake Bay and vicinity. Estuar Coast Shelf Sci 23: 115-130

Radach G, Moll A (1993) Estimation of the variability of production by simulating annual cycles of phytoplankton in the central North Sea. Prog Oceanogr 31:339-419

Rhodes LL, Haywood AJ, Ballantine WJ, MacKenzie AL (1993) Algal blooms and climate anomalies in north-east New Zealand, August-December 1992. NZ J Mar Freshwat Res 27(4):419-430

Ricard M (1987) Atlas du phytoplancton marin. Vol. II. Diatomophycées. Editions du CNRS, Paris 
Robert P, Escoufier Y (1976) A unifying tool for linear multivariate statistical methods: the RV-coefficient. Appl Statist 25:257

Smayda TJ (1980) Phytoplankton succession. In: Morris (ed) Physiological ecology of phytoplankton I. Blackwell, Oxford, p 493-570

Smayda TJ (1997) Harmful algal blooms: their ecophysiology and general relevance to phytoplankton blooms in the sea. Limnol Oceanogr 42:1137-1153

Smayda TJ, Reynolds CS (2001) Community assembly in marine phytoplankton: application of recent models to harmful dinoflagellate blooms. J Plankton Res 23: $447-461$

Thioulouse J, Chessel D (1987) Les analyses multi-tableaux en écologie factorielle. I. De la typologie d'état à la typologie de fonctionnement par l'analyse triadique. Acta Oecologica 8:463-480

Thomas CR (1996) Identifying marine diatoms and dinoflagellates. Academic Press, London

Editorial responsibility: Otto Kinne (Editor),

Oldendorf/Luhe, Germany
Thomas WH, Gibson CH (1990) Effects of small-scale turbulence on microalgae. J Appl Phycol 2:71-77

Tucker LR (1964) The extension of factor analysis to threedimensional matrices. In: Gullinkson $\mathrm{H}$, Frederiksen $\mathrm{N}$ (eds) Contributions to mathematical psychology. Rinehart \& Winston, New York, p 110-119

Vaulot D, Frisoni GF (1986) Phytoplanktonic productivity and nutrients in five Mediterranean lagoons. Oceanol Acta 9: $57-63$

Videau C, Leveau M (1990) Phytoplanktonic biomass and productivity in the Rhône River plume in spring time. CR Acad Sci Paris Ser III 311:219-224

Videau C, Ryckaert M, L'Helguen S (1998) Phytoplankton in the Bay of Seine (France): influence of the river plume on primary productivity. Oceanol Acta 21:907-921 (in French with English abstract)

Zingone A, Enevoldsen HO (2000) The diversity of harmful algal blooms: a challenge for science and management. Ocean Coastal Manage 43:725-748

Submitted: March 5, 2002 Accepted: June 26, 2002

Proofs received from author(s): October 15, 2002 